\title{
STRUCTURAL AND ELECTRICAL PROPERTIES OF GEOPOLYMER MATERIALS BASED ON DIFFERENT PRECURSORS (KAOLIN, BENTONITE AND DIATOMITE)
}

\author{
Ljiljana M. Kljajević ${ }^{*}$, Zuzana Melichova ${ }^{2}$, Marija D. Stojmenović1, Bratislav Ž. Todorović́ ${ }^{3}$, \\ Vladimir B. Pavlović ${ }^{4}$, Nada M. Čitaković ${ }^{5}$, Snežana S. Nenadović ${ }^{1}$ \\ ${ }^{1}$ Laboratory for Materials Science, Vinča Institute of Nuclear Sciences, University of Belgrade, \\ 11000 Belgrade, Serbia \\ ${ }^{2}$ Faculty of Natural Sciences, Matej Bel University, Banská Bystrica, Slovakia \\ ${ }^{3}$ Faculty of Technology of Leskovac, University of Niš, Leskovac, Serbia \\ ${ }^{4}$ Institute of Technical Sciences of the Serbian Academy of Sciences and Arts, Knez Mihailova 35/IV, \\ University of Belgrade, 11000 Belgrade, Serbia \\ ${ }^{5}$ University of Defence, Military Academy, Generala Pavla Jurišića Šturma 33, 11000 Belgrade, Serbia \\ ljiljanamkljajevic@gmail.com
}

\begin{abstract}
Geopolymers (GP) were successfully synthesized from metabentonite (MB), metadiatomite (MD) and metakaolinite (MK). Characterization of their phase structure and microstructure was performed by XRD, FTIR, SEM/EDX methods. A SEM micrograph of GPMD shows a homogeneous surface with some longitudinal cavities in the gel, and it is significantly different from the micrographs of the other two geopolymer samples, GPMB and GPMK. A considerable amount of unreacted particles, as well as the presence of pores in the geopolymer matrix of GPMK and GPMD, indicate an incomplete reaction in the system. Aluminosilicate inorganic polymers, geopolymers, are quasi solid electrolytes which possess a high electrical conductivity at room temperature in relation to materials of similar chemical composition. The highest conductivity was found for the sample obtained from GPMK, amounting to $2.14 \times 10^{-2}$ $\Omega^{-1} \mathrm{~cm}^{-1}$ at $700{ }^{\circ} \mathrm{C}$. The corresponding activation energies of conductivity for this sample amounted to $0.33 \mathrm{eV}$ in the temperature range of $500-700{ }^{\circ} \mathrm{C}$. The geopolymer synthesized from metakaolin has good ionic conductivity values, which recommends it for use as an alternative material for an SOFC (Solid Oxide Fuel Cell).
\end{abstract}

Keywords: metabentonite; metakaolin; metadiatomite; geopolymer; electrical conductivity

\section{СТРУКТУРНИ И ЕЛЕКТРИЧНИ СВОЈСТВА НА ГЕОПОЛИМЕРНИ МАТЕРИЈАЛИ БАЗИРАНИ НА РАЗЛИЧНИ ПРЕКУРЗОРИ (КАЛОЛИН, БЕНТОНИТ И ДИАТОМИТ)}

Успешно беа синтетизирани геополимери (GP) од метабентонит (MB), метадиатомит (MD) и метакаолинит (MK). Карактеризацијата на нивните фазни структури беше определена со методите на XRD, FTIR и SEM/EDX. Микрографот SEM на GPMD покажува хомогена површина со лонгитудинални празнини во гелот и значајно се разликува од микрографите на двата други примероци на геополимери, GPMB и GPMK. Значителна количина на неизреагирани честички, како и присуство на пори во геополимерната матрица на GPMK и GPMD укажуваат на нецелосна реакција на системите. Алумосиликатните неоргански полимери, геополимери, се квазицврсти електролити што имаат висока електрична спроводливост на собна температура во однос на материјалите со сличен хемиски состав. Највисока спроводливост е најдена кај примерокот од GPMK и изнесува $2,14 \times 10^{-2} \Omega^{-1} \mathrm{~cm}^{-1}$ на $700^{\circ} \mathrm{C}$. Соодветните активациони енергии на кондуктивноста за овој примерок изнесуваат до $0,33 \mathrm{eV}$ во температурниот опсег од $500-700{ }^{\circ} \mathrm{C}$. 
Геополимерот синтетизиран од метакаолин има добри вредности на јонска спроводливост, што го прави погоден за употреба како алтернативен материјал на SOFC (Горивна ќелија од цврст оксид).

Клучни зборови: метабентонит; метакаолин; метадиатомит; геополимер; електрична спроводливост

\section{INTRODUCTION}

Aluminosilicate inorganic polymers, also called geopolymers, are materials formed under high alkali conditions from solid aluminosilicate and alkali silicate solutions [1]. Cross linking of tetrahedral $\mathrm{AlO}_{4}$ and $\mathrm{SiO}_{4}$ units built three dimensional structures of the geopolymer, a long chain inorganic polymer. The linkages of $\mathrm{AlO}_{4}$ and $\mathrm{SiO}_{4}$ units require charge balancing from alkali ions such as $\mathrm{M}^{+}\left(\mathrm{Li}^{+}, \mathrm{Na}^{+}\right.$and $\left.\mathrm{K}^{+}\right)$. In the aluminosilicate geopolymer materials, the $\mathrm{M}^{+}$, water molecule, and hydroxyl are the most important factors influencing electrical conductivity and the dielectric property at room temperature. Cui et al. [2] and Novais et al. [3] reported that the synthesized geopolymer possessed a high electrical conductivity at room temperature. This is unlike some alumosilicate and silicate minerals such as clay, feldspar, and quartz that are electrical insulators at room temperature, but due to ionic conduction they can behave like semiconductors and conductors when temperature is increased [4]. Generally, the electrical conductivity of these kinds of minerals increases exponentially with increasing temperature, because the mobility of the charge carrier is a thermally activated process [4-6]. Aluminosilicates are quasi solid electrolytes [7, 8] in which protons move along the net of hydrogen bonds. Therefore, the diffusion rate of the protons should be analogous to the same parameters in aqueous solutions without a dependence on whether the diffusion process is carried out by grains (layers) or by grain boundaries. It is essential that proton conductors possess mixed ion-electron (electronhole) conductivity [8].

Such a high level of electrical conductivity is expected to play an important role in the fast ionic conduction that is used for solid-state batteries and electrochemical sensors. As a very well developed method, the complex impedance method is used to study the electrical properties of solid electrolytes, because, in addition to the total ionic conductivity [9-17], it enables obtaining information about the separate contribution of the bulk and the grain boundary resistance, as well as the electrode process. Generally, the impedance spec- tra are presented as the negative of the imaginary component of impedance $\left(-Z_{\text {imag }}\right)$ versus the real component of impedance $\left(Z_{\text {real }}\right)$ (i.e., as a Nyquist plot). A typical Nyquist plot of an electrolyte in solid state consists of three semicircles, where semicircles at high and intermediate frequencies are ascribed to the bulk and grain boundaries, while a semicircle at low frequency represents the electrode process contribution [18]. For high and intermediate frequency semicircles, two serially connected RC circuits are characteristic, and both of these contain one resistive and one capacitive element bonded in a parallel arrangement, the capacitive element being a distributed (frequency dependent) one. Such equivalent circuits with both constant [19-21] and distributed [22] capacitive elements have been widely applied in the literature related to sintered ceramics.

Hence, this paper presents a study of the physicochemical characteristics of raw materials/metaphases of diatomite, bentonite, and kaolin used for geopolymerization reactions, and the microstructure of different geopolymer materials. In accordance with the possibility the geopolymer can be used as solid oxide fuel cells, the ionic conductivity of the obtained geopolymers has been investigated.

\section{MATERIALS AND METHODS}

Geopolymers (GP) were synthesized from metadiatomite (MD), metabentonite (MB) and metakaolinite (MK). The diatomite and kaolin originate from Rudovci, Lazarevac, Serbia, while bentonite originates from the Lieskovec deposit, (near Zvolen, Central Slovakia). This deposit is currently mined by Envigeo Inc., Slovakia.

The synthesis of GP involves the following steps: grinding and then thermally treating the raw materials, the preparation of an alkali activator, mixing the solid and liquid phases, and finally the geopolymerization reaction. Previously milled and sieved raw materials (diatomite, bentonite and kaolin) were calcined in an electric oven, in air, at $750{ }^{\circ} \mathrm{C}$ for 1 hour; the heating rate from room temperature up to $750^{\circ} \mathrm{C}$ was $10^{\circ} \mathrm{C} / \mathrm{min}$., the cooling was spontaneous. The geopolymers (GP) were formed from all of the thermally treated samples, 
and the alkaline solutions (solid/liquid ratio was 1) were mixed for $20 \mathrm{~min}$ and then left at room temperature for one day. Finally, the mixtures were kept in a sample drying oven for two days at 60 ${ }^{\circ} \mathrm{C}$. The alkaline solution was prepared from sodium silicate (volume ratio $\mathrm{Na}_{2} \mathrm{SiO}_{3} / \mathrm{NaOH}=1.5$ ) and an aqueous solution of $\mathrm{NaOH}, c_{\mathrm{NaOH}}=$ $2 \mathrm{~mol} / \mathrm{dm}^{3}-2 \mathrm{M} \mathrm{NaOH}$ (analytical grade), in accordance with our previous research [23-25]. After this reaction step, all samples were aged for 28 days. The required time period to finish the polymerization process was chosen from the literature data [26]. The chemical analysis of all raw materials (diatomite, bentonite and kaolin) showed different values of the Si/Al ratio. It was 7.8 for diatomite, 3.0 for bentonite and 2.3 for kaolin. The functional groups of all considered samples were studied using FTIR spectroscopy at room temperature (Bomem (Hartmann \& Braun) MB-100 spectrometer). Samples were finely powdered and dispersed evenly in anhydrous potassium bromide $(\mathrm{KBr})$ pellets $(1.5 \mathrm{mg} / 150 \mathrm{mg} \mathrm{KBr})$. The spectral data of the samples were collected in the 4000-400 $\mathrm{cm}^{-1}$ region with a resolution of $4 \mathrm{~cm}^{-1}$.

All samples, raw materials, metaphases and geopolymer samples, were characterized by X-ray diffraction analysis (XRD) using an Ultima IV Rigaku diffractometer equipped with $\mathrm{Cu} K \alpha_{1,2}$ radiation and with a generator voltage of $40.0 \mathrm{kV}$ and a generator current of $40.0 \mathrm{~mA}$. The $2 \theta$ range of $5^{\circ}-80^{\circ}$ was used for all powders in a continuous scan mode with a scanning step of $0.02^{\circ}$ at scan rate of $5 \% \mathrm{~min}$.

The microstructure of all samples of GP was observed on Au-coated samples using a JEOL JSM $6390 \mathrm{LV}$ electron microscope at $25 \mathrm{kV}$.

After finishing the polymerization process, the samples (GPMD, GPMB and GPMK) were cast in the form of pellets, and their ionic conductivity was measured by the complex impedance method in the frequency range $10-1 \mathrm{MHz}$ using an Interface 1000 Potentiostat/Galvanostat/ZRA and EIS300 Electrochemical Impedance Spectroscopy Software. The measurements were conducted in air and in the temperature range $300-700{ }^{\circ} \mathrm{C}$ with 50 ${ }^{\circ} \mathrm{C}$ increments. The amplitude of the applied sinusoidal voltage signal was $20 \mathrm{mV}$. A thin layer of high conductivity silver paste was applied onto both sides of the sample pellets in order to provide good electrical contact between the electrolyte and electrodes. The samples were placed between the silver plates in a ceramic holder that was heated by vertical oven. A Pt-Rh thermocouple located just below the bottom silver plate was used for temperature monitoring. The impedance plots obtained experimentally were fitted by means of the software ZViews for Windows (Version3.2b). The resistance values were determined from the impedance diagrams recorded at various temperatures. The specific conductance was calculated from the resistance data using the dimensions of the sample pellets.

In our work, the original Nyquist plots [18] were recorded in the available frequency range (1 $\mathrm{Hz}-100 \mathrm{kHz}$ ). The high-frequency semicircle may be attributed to a parallel connection of the bulk resistance $\left(R_{b}\right)$ of crystallite grains and the geometric capacitance $\left(C_{g}\right)$ of the sample. If the impedance semicircles were clearly separated, i.e. $R_{b} C_{g}<<$ $R_{g b} C_{g b}$, the values of $R_{b}$ and $R_{g b}$ may be read separately as the low-frequency intercept of the semicircles with the real axis. By means of the frequency corresponding to the high-frequency semicircle maximum, $\omega_{\max , b}$, geometric capacitance can be calculated according to the following equation:

$$
\omega_{\max , b}=1 / R_{b} \cdot C_{b}
$$

where $\left(R_{b}\right)$ is the bulk resistance of crystallite grains and $\left(C_{g}\right)$ is the geometric capacitance of the sample.

The low-frequency semicircle may be attributed to the grain boundary resistance $\left(R_{i g}\right)$ in parallel connection with the intergranular capacitance $\left(C_{i g}\right.$. In this case, by means of the frequency which refers to the semicircle maximum, intergranular capacitance can be calculated using the well-known equation:

$$
\omega_{\max , i g}=1 / R_{i g} \cdot C_{i g}
$$

Thus, with increasing temperature, both resistance elements $\left(R_{b}\right.$ and $\left.R_{g b}\right)$ decrease, which causes an increase in $\omega_{\max }$. In this case, the whole region of the impedance points shifts towards the low-frequency semicircle. At higher temperatures, instead of $\mathrm{R}_{\mathrm{b}}$ and $R_{g b}$ separately, only the whole sum $R_{b}+R_{i g}$ becomes readable in the available frequency range.

\section{RESULTS AND DISCUSSION}

\subsection{FTIR-analysis}

Phase evolution for geopolymers made from metadiatomite, metabentonite and metakaolin can be monitored by FTIR absorption peaks which correspond to the frequencies of vibrations between the bonds of the atoms making up the material, as shown in Figure 1. 


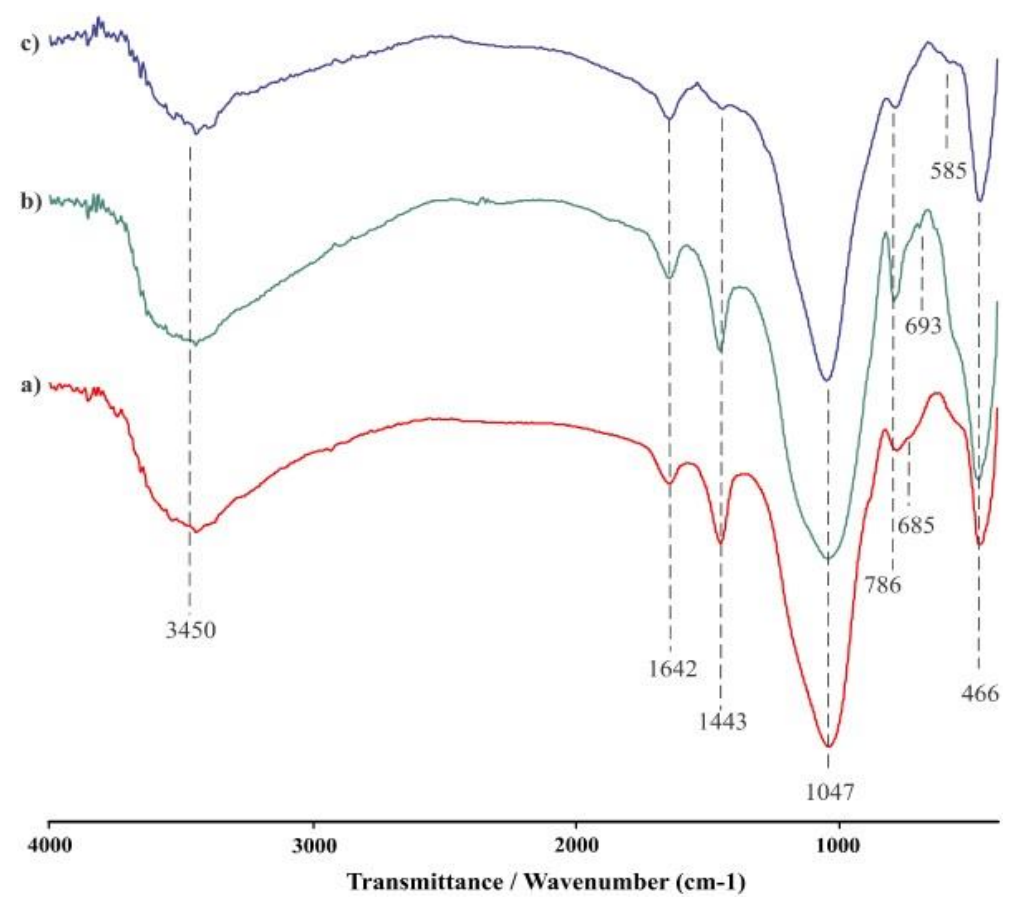

Fig. 1. FTIR spectrum of GP obtained from precursor metakaolin (GPMK) (a) metabentonite (GPMB) (b) and metadiatomite (GPMD) (c)

Diffuse bands in all samples at about 3450 and $1640 \mathrm{~cm}^{-1}$ were observed, and these are attributed to the stretching and deformation vibration of the physically associated water $(\mathrm{O}-\mathrm{H})$ molecule on the surface. Peaks at $1443 \mathrm{~cm}^{-1}$ are due to the asymmetric stretching mode vibration of the O-C$\mathrm{O}$. Peaks at $1047 \mathrm{~cm}^{-1}$ are stretching vibrations of the Si-O-Si, actually of Si-O-M (M = Al, $\mathrm{Mg}$ and $\mathrm{Fe})$. The band around $786 \mathrm{~cm}^{-1}$ indicates the existence of the Al-O and Si-O-Al groups. Vibration bands at $466 \mathrm{~cm}^{-1}$ and $585 \mathrm{~cm}^{-1}$ are assigned to the tetrahedral bending mode of $\mathrm{T}-\mathrm{O}(\mathrm{T}=\mathrm{Si}$ or $\mathrm{Al})$ and the bending mode of Si-O-Al, respectively [27, 28]. Probably, after the geopolymerization, the $\mathrm{Si}-$ $\mathrm{O}-\mathrm{Al}$ band at $786 \mathrm{~cm}^{-1}$ in the meta phase is replaced by several weaker bands in the range from $585 \mathrm{~cm}^{-1}$ to $685 \mathrm{~cm}^{-1}$.

The major difference is the vibration observed at wavenumber $786 \mathrm{~cm}^{-1}$, which is the most expressive for GPMB (Fig. 1b).The bands in the region $800-600 \mathrm{~cm}^{-1}$ are associated with $\mathrm{Si}-\mathrm{O}-\mathrm{Al}$ vibrations [29, 30]. In case of both GPMD and GPMK, the same band is weaker and shifted to a lower wavenumber.

\subsection{Microstructure analysis}

\subsubsection{XRD analysis}

Figure 2 shows the XRD patterns of diatomite, metadiatomite and geopolymeric materials obtained from thermally treated diatomite. The amorphous phase of geopolymers was indicated by the broad hump in the region of $2 \theta 25-35^{\circ}$. Roode and Hemings [31] examined sodium silicate model glasses in which sodium content varied from zero to $50 \%$. From the corresponding X-ray diffraction patterns, it can be observed that the halo is shown at a low angle composition at $22-24^{\circ} 2 \theta$ max, which corresponds to three-dimensional networks and at a high angle composition at $30-34^{\circ} 2 \theta$ max, which corresponds to low molecular weight silicate (dimer, monomer).

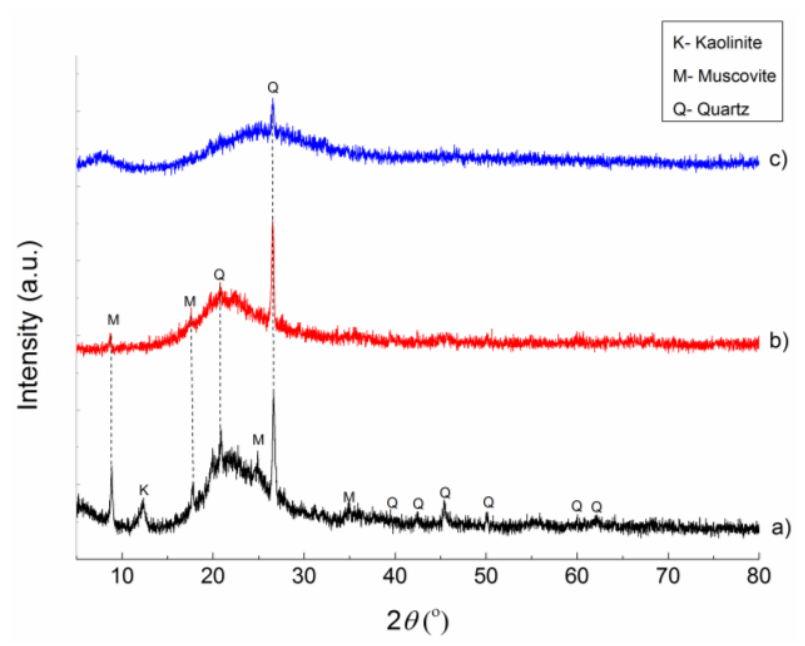

Fig. 2. XRD patterns of the diatomite (a) metadiatomite (b) and geopolymer samples GPMD (c) 
Figure 2c shows a halo with a maximum value of about $25^{\circ} 2 \theta$ which, on the basis of the previously mentioned reference, indicates that the structure is close to a three-dimensional network.

Figure 3 shows the XRD patterns of bentonite, metabentonite, and metabentonite based geopolymer samples. The semi-crystalline structure of the geopolymer was obtained from thermally treated bentonite and alkaline activator. The results of the characterization of bentonite by XRD showed that bentonite from the Lieskovac area is generally composed of four types of minerals: montmorillonite (pdf card No: 00-058-2038), kaolinite (pdf card No: 00-058-2005), quartz (card No: 89279), and cristobalit (pdf card No: 00-003-0267). The dominant bentonite peaks are the ones which correspond to montmorillonite and cristobalite [32]. Structural modification of montmorillonite was caused by thermal treatment of the bentonite matrix at $750{ }^{\circ} \mathrm{C}$, in which the layered structure is lost. In this case, the amorphous structure is enriched by fine crystallites incorporated in the amorphous mass of the alumosilicate which cannot be detected by X-ray structure analysis.

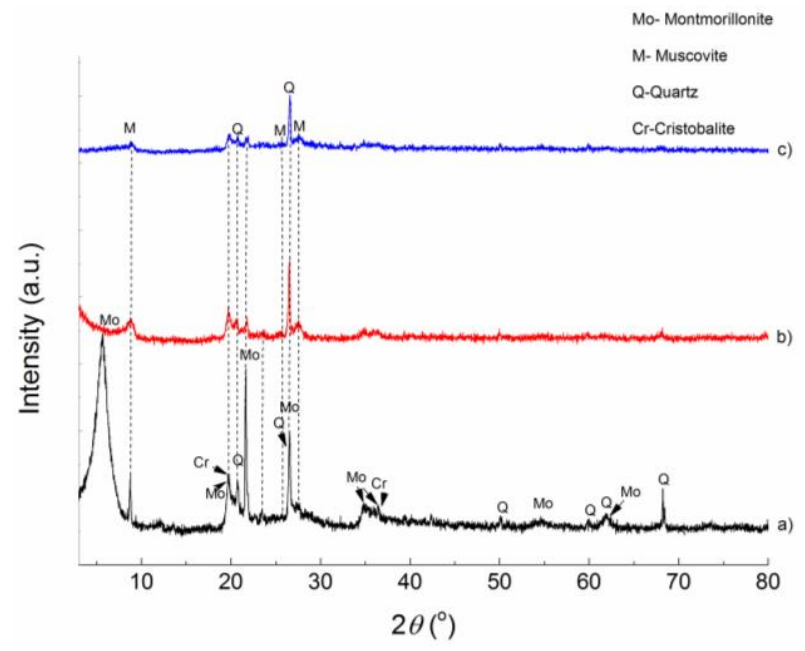

Fig. 3. XRD patterns of the bentonite (a) metabentonite( b) and geopolymer samples GPMB (c)

Figure 4 shows XRD patterns of kaolin, metakaolin, and geopolymer obtained from thermally treated kaolin. Quartz is one of the minerals that are commonly found in the earth's continental crust. This mineral has a hexagonal crystal structure made of trigonal crystallized silica (silicon dioxide $\left.\left(\mathrm{SiO}_{2}\right)\right)$. The clay minerals prevailed in the sample, with muscovite (card No: 17049) being the dominant phase, followed by kaolinite (pdf card No: 00-058-2005). Metakaolin contains levels of impurities, primarily quartz (card No: 89279) and muscovite (card No: 17049). The effect of these impurities is limited by both their low dissolution and the inability of the products of their dissolution to affect the formation mechanism. The amorphous halo was detected in both metakaolin and metakaolin based geopolymer samples. Figure 4c (XRD of GPMK) shows a halo with the maximum value of about $26^{\circ} 2 \theta$.

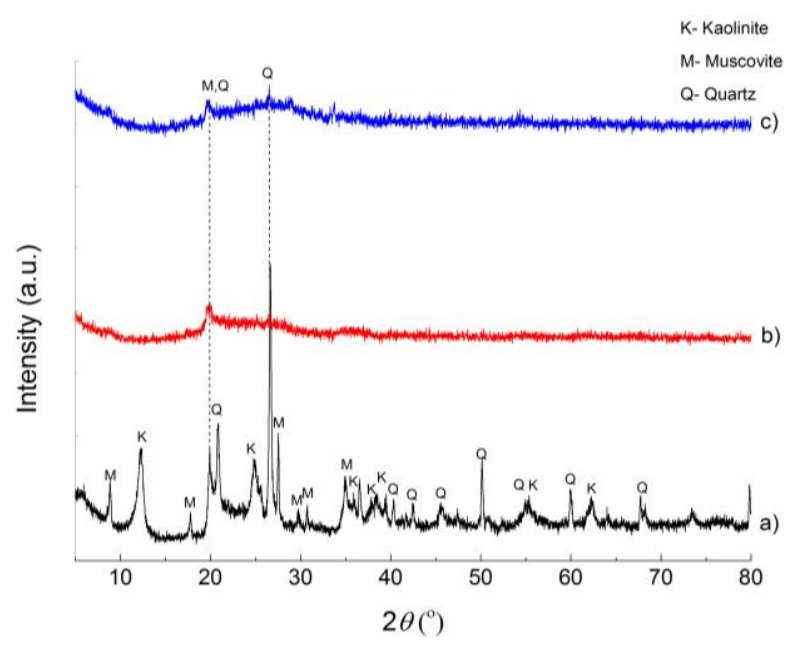

Fig. 4. XRD patterns of the kaolin (a) metakaolin (b) and geopolymer samples GPMK (c)

\subsubsection{SEM analysis}

The SEM micrographs of geopolymers are shown in Figure 5. All of the geopolymer samples (GPMD, GPMB, and GPMK) were analyzed in a powder state. SEM micrographs with EDS analysis (Fig. 5) show the morphology changes that occurred in the hardened GPMD, GPMB, and GPMK samples. In all samples studied, the gel formed from $\mathrm{Si}, \mathrm{Al}, \mathrm{Na}$ and the other elements present was observed as the major product, along with the unreacted metaphase particles, during the aging time up to 28 days. The geopolymeric materials are composed of solid particles chemically connected with an inorganic polymeric binder formed during the geopolymerization process. SEM microphotographs presented in Figure 5 show that samples synthesized from metakaolin and metabentonite have a more porous structure compared to the SEM image of metadiatoms. The Si/Al ratio for geopolymer synthesized from metakaolin is 2.1 , while the ratio for the geopolymer synthesized from bentonite is two times higher, 4.2. The geopolymer synthesized from diatoms has the highest $\mathrm{Si} / \mathrm{Al}$ ratio, which is 13.4. In a medium with a high concentration of dissolved silica, the species is dissolved from the surface of the metaphases, and particles migrate from the surface into the bulk solution [33]. 
Figure 5a presents the SEM micrographs of GPMD, which are significantly different from the other two. In this case, it probably came to crosslinking that resulted in the creation of a homogeneous surface with some longitudinal cavities (Fig. 5a). These cavities pass through sodium silicate gel (Fig. 5a) with small number of individual and grouped particles on their surface.

The microstructures of GPMB and GPMK were highly inhomogeneous, and the matrix was full of unreacted platy grains of different sizes. The considerable amount of unreacted particles as well as the presence of pores in the geopolymer matrix (Fig. 5b and c) could be indicate an incomplete reaction in the system. Uneven forms of small particles grouped into agglomerates and individually arranged particles across the surface of large geopolymer plates are visible in Figure 5b and Figure 5c. All particles were predominantly of different sizes and had smooth surfaces [34].

If the silica content increases (EDS analysis), the degree of reaction taking place in a geopolymer forming paste decreases according to observations of Provis and Van Deventer [35]. An increase of GP gel content is influenced by an increase in the $\mathrm{Si} / \mathrm{Al}$ ratio. The physical and chemical properties of the geopolymer depend on the $\mathrm{Si} / \mathrm{Al}$ ratios [36].
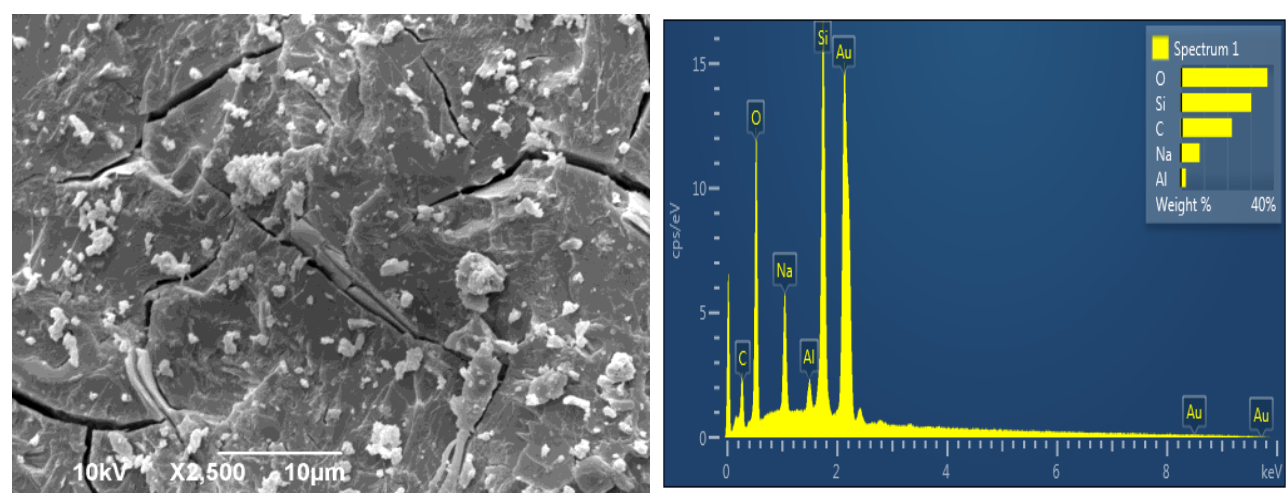

a)
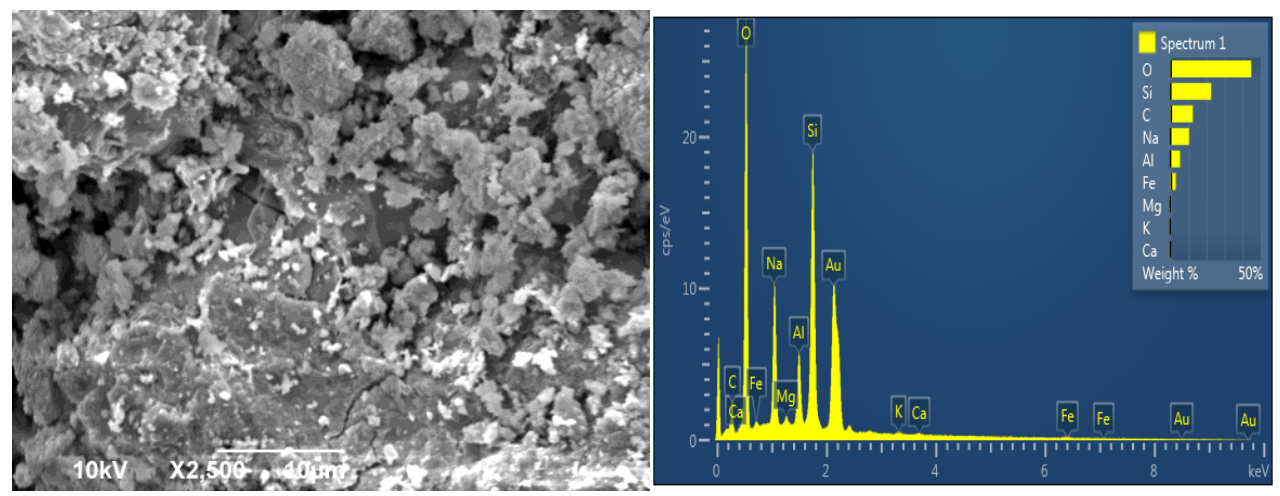

b)
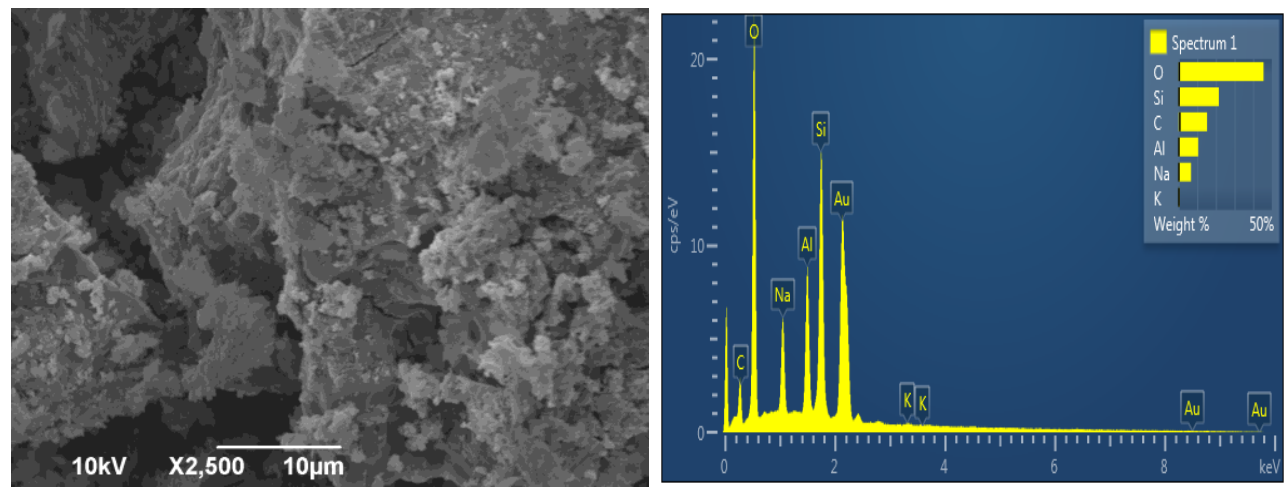

c)

Fig. 5. SEM and EDS of GPMD (a) GPMB (b) and GPMK (c) 
Additionally, for all three geopolymer samples ( $\mathrm{Na}, \mathrm{Si}$ and $\mathrm{Al}$ ), a small amount of $\mathrm{Fe}, \mathrm{Ca}, \mathrm{K}$, and $\mathrm{Mg}$ were also observed in the gel by EDS analysis (Fig. 5). These remnants (Fe, $\mathrm{Ca}, \mathrm{K}, \mathrm{Mg}$ ) obviously represent the metaphases which, for various reasons, did not dissolve during alkali activation. Lloyd et al. [37] suggested that during alkaline activation, these remnants may even disperse through the gel. The properties of the resulting geopolymer systems depend not only on the composition and reactivity of the metaphases used but also on the initial $\mathrm{Si} / \mathrm{Al}$ ratio in the mixture, which is different for all metaphases presented here [38].

\subsection{Electrical conductivity}

Complex impedance plots of the GPMK sample, measured in air atmosphere at two temperature intervals, $500-600{ }^{\circ} \mathrm{C}$ and $650-700{ }^{\circ} \mathrm{C}$, are presented in Figure 6.
As can be seen (Figures 6a and 6b), during the GPMK ionic conductivity test, with the increase in temperature, high and medium frequency semicircles disappear. At higher temperatures, the time constants associated with the bulk and grain boundary impedances are much lower than those associated with the electrode interface. As a result, semicircles due to bulk and grain boundaries disappear (Fig. 6b), and only a single semicircle due to electrode interfacial processes can be observed. In this case, only the whole sum $R_{b}+R_{i g}$ became readable, and the values of total resistance were estimated from the experimental cross section obtained from semicircles with the real component of impedance $\left(Z_{\text {real }}\right)$. This intercept is marked by arrows in Fig. 6 (insets). New semicircles were formed in a low-frequency region. These are particularly visible at the temperatures 650 and $700{ }^{\circ} \mathrm{C}$ (Fig. 6b).
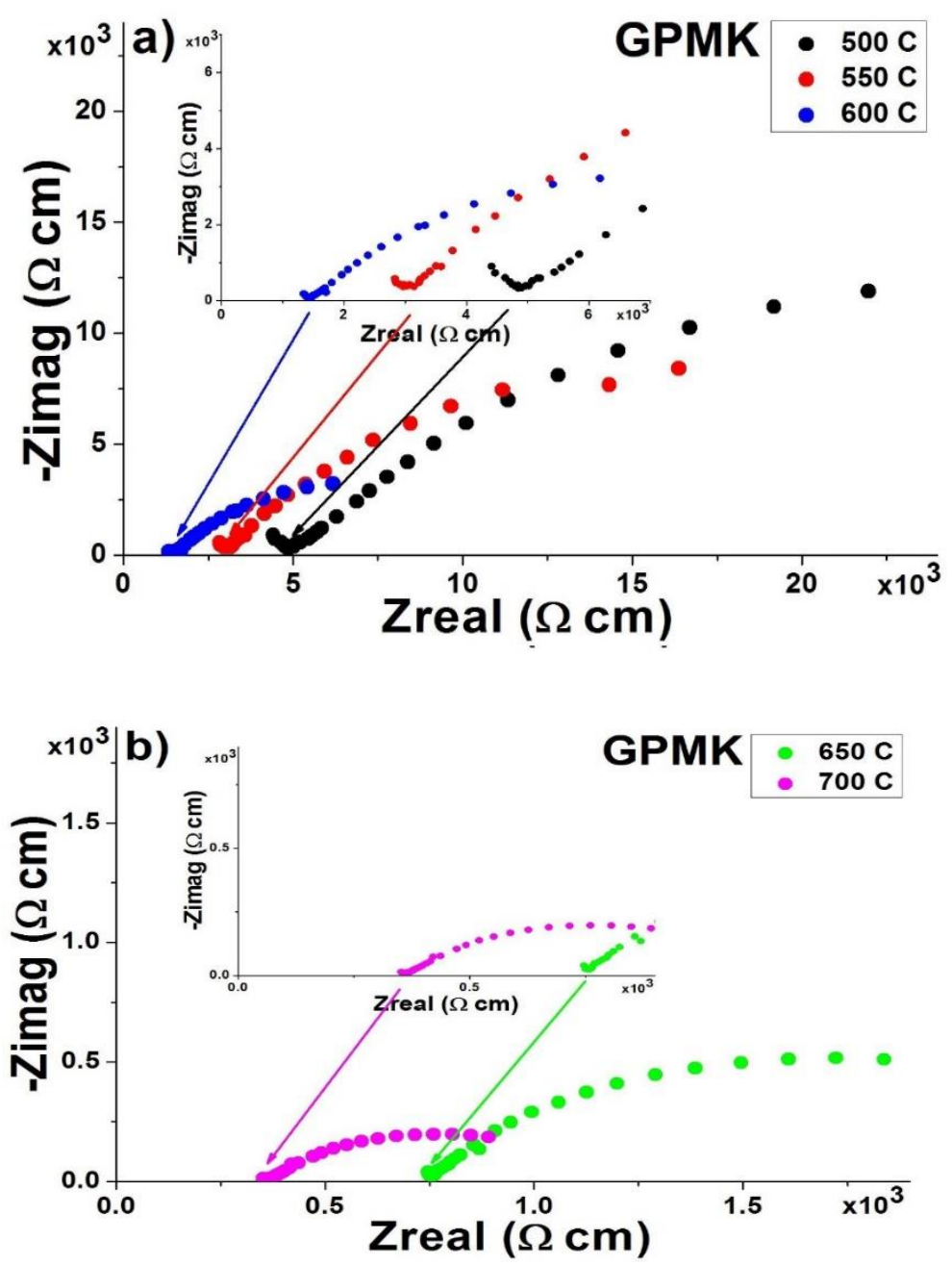

Fig.6. Complex impedance plots of the GPMK sample measured at the following temperatures: a) 500-600 ${ }^{\circ} \mathrm{C}$ and b) $650-700{ }^{\circ} \mathrm{C}$, in air atmosphere. The working temperatures are indicated on each diagram.

The arrows indicate the points on the real axis corresponding to the readings $R_{\mathrm{b}}$ and $R_{\mathrm{b}}+R_{\mathrm{ig}}$. 
The values of the ionic conductivity for all geopolymer samples (GPMB, GPMK and GPMD) are shown in Table 1. By comparing the results obtained, it can be noted that the highest values of ionic conductivity were shown by the GPMK sample. The actual values of the total ionic conductivity of the mentioned sample amount to $2.14 \times 10^{-2}$ $\Omega^{-1} \mathrm{~cm}^{-1}$ at $700{ }^{\circ} \mathrm{C}$. Additionally, comparing the obtained results of ionic conductivity with the literature data [38], it can be noted that the values measured here are higher by an entire order of magnitude. More specifically, the values of ionic conductivity observed at $700{ }^{\circ} \mathrm{C}$ in this paper were similar to literature values obtained at $900{ }^{\circ} \mathrm{C}$ [39]. In addition, the conductivities of the samples measured in this study are similar to the literature data on similar oxygen ion conductors $[9,22,39]$. These kinds of inorganic polymers could be related to smart properties such as stimuli responsive physical properties (conductivity). Temperatureresponsive inorganic polymers are materials that undergo changes due to changes of temperature.

Table 1

The temperature dependence of total ionic conductivity $(\kappa)$ of the synthesized GPMB, GPMK and GPMD samples

\begin{tabular}{|c|c|c|c|c|c|c|}
\hline Composition & $\begin{array}{c}\kappa \\
\left(\Omega^{-1} \mathrm{~cm}^{-1}\right) \\
5_{000}{ }^{\circ} \mathbf{C}\end{array}$ & $\begin{array}{c}\kappa \\
\left(\Omega^{-1} \mathrm{~cm}^{-1}\right) \\
550^{\circ} \mathbf{C}\end{array}$ & $\begin{array}{c}\kappa \\
\left(\Omega^{-1} \mathrm{~cm}^{-1}\right) \\
\mathbf{6 0 0}^{\circ} \mathbf{C}\end{array}$ & $\begin{array}{c}\kappa \\
\left(\Omega^{-1} \mathrm{~cm}^{-1}\right) \\
\mathbf{6 5 0}^{\circ} \mathbf{C}\end{array}$ & $\begin{array}{c}\kappa \\
\left(\Omega^{-1} \mathrm{~cm}^{-1}\right) \\
\mathbf{7 0 0}^{\circ} \mathrm{C}\end{array}$ & $\begin{array}{c}E_{a} \\
(e V) \\
\mathbf{5 0 0 - 7 0 0}^{\circ} \mathbf{C}\end{array}$ \\
\hline GPMB & $6.26 \times 10^{-4}$ & $9.58 \times 10^{-4}$ & $2.22 \times 10^{-3}$ & $4.46 \times 10^{-3}$ & $6.15 \times 10^{-3}$ & 0.35 \\
\hline GPMK & $2.33 \times 10^{-3}$ & $3.62 \times 10^{-3}$ & $7.21 \times 10^{-3}$ & $1.51 \times 10^{-2}$ & $2.14 \times 10^{-2}$ & 0.33 \\
\hline GPMD & $1.04 \times 10^{-4}$ & $3.92 \times 10^{-4}$ & $8.55 \times 10^{-4}$ & $1.28 \times 10^{-3}$ & $1.89 \times 10^{-3}$ & 0.40 \\
\hline
\end{tabular}

According to the results of total ionic conductivity $(\kappa)$ of the synthesized samples listed in Table 1 , the dependence $\log \kappa=f(1 / T)$ of the synthesized sample GPMK is presented in Figure 7. Activation energies $\left(E_{a}\right)$ were calculated from $\mathrm{Ar}$ rhenius plots according to the derived equation:

$$
\ln (\sigma \cdot T)=\ln A-\frac{E_{a}}{k} \cdot \frac{1}{T}
$$

where $\sigma$ is the conductivity, $T$ is the absolute temperature, $A$ is the pre-exponential factor, and $k$ is the Boltzmann constant. Activation energy $\left(E_{a}\right)$ for the total ionic conductivity of synthesized samples is presented in Table 1. Based on the research of different authors and literature data, it can be concluded that the value of $E_{\mathrm{a}}$ examined in our work is lower when compared to the activation energy for similar ion conductors $[9,11,12,14,16]$. It can be said that this is a consequence of the well-ordered structures and better processing of the obtained powders, which allows easier activation of conductivity carriers and decreases $E_{a}$.

Thus, it must be pointed out that the impedance spectra measured at temperatures above $500{ }^{\circ} \mathrm{C}$ are reproducible, but several factors could have an effect on impedance measurements such as incomplete contact between sample and electrode, a short circuit through a less resistive path in samples, and a different presence of moisture in samples. Additionally, the mentioned samples can display differ- ences in density, grain size, and porosity, which also may be responsible for the measured conductivity.

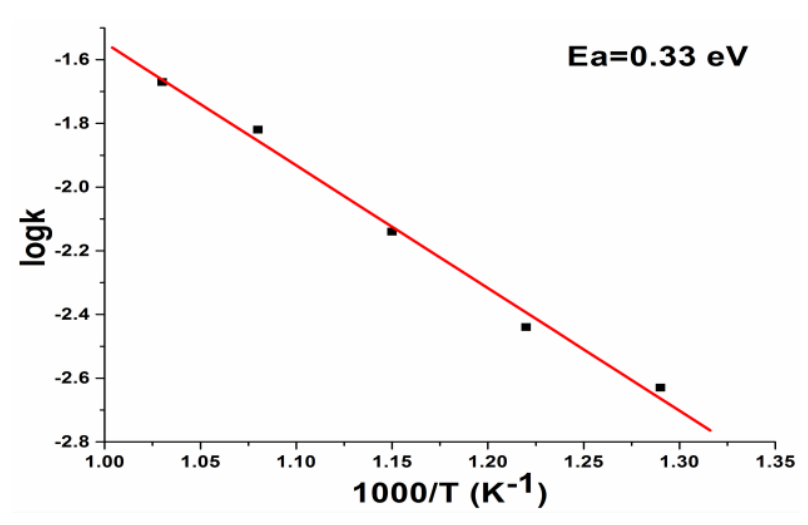

Fig. 7. The dependence $\log k=f(1 / T)$ of the synthesized sample GPMK

\section{CONCLUSION}

In this research, XRD analysis has confirmed that the mineralogical composition which is present in the raw material is found in the geopolymer. As for all three FTIR spectra of GPMD, GPMB and GPMK, there are differences in strength of the band for $\mathrm{Al}-\mathrm{O}$ and $\mathrm{Si}-\mathrm{O}-\mathrm{Al}$ at $786 \mathrm{~cm}^{-1}$. After 28 days of curing time, the SEM micrographs of alkali activated aluminosilicate clearly showed that a dense gel is formed on the surface of the geopolymer. The GPMB and GPMK 
show denser and more agglomerated particles. The electrical conductivity of geopolymers increases exponentially with increasing temperature, because the mobility of the charge carrier is a thermally activated process. It was also confirmed that the obtained geopolymers, synthesized from alumosilicate (kaolin, bentonite and diatom), are proton charge carriers.

The geopolymer synthesized from metakaolin has good ionic conductivity values, which recommends it for use as an alternative material for SOFCs (Solid Oxide Fuel Cell). The physicochemical properties of the metakaolin material obtained are very similar to those obtained with ceriumsynthesized materials. Material synthesized from metakaolin is far cheaper and belongs to ecological materials recommended for new green technologies. Owing to free sintering and low cost, geopolymer fabrication is one of the efficient methods to form a fast inorganic ionic conductor.

Acknowledgement. Ministry of Education, Science and Technological Development of the Republic of Serbia [III 45012 and III 45005]; In Slovakia grant from the Slovak Grant Agency VEGA No. 1/0538/15 and the project "Restoration and construction of infrastructure for ecological and environmental research at Matej Bel University in Banská Bystrica", ITMS 26210120024. Our special thanks go to Gordana Jelić, $\mathrm{Ph} . \mathrm{D}$, a professor of English language, for her support in the translation of this paper.

\section{REFERENCES}

[1] J. Davidovits, Geopolymers-inorganic polymeric new materials, J. Therm. Anal. 37 (8), 1633-1656 (1991).

[2] X-M. Cui, G-J Zheng, Y. C. Han, F. Su, J. Zhou, A study on electrical conductivity of chemosynthetic $\mathrm{Al}_{2} \mathrm{O}_{3}-2 \mathrm{SiO}_{2}$ geopolymer materials. J. Power Sources 184, 652-656 (2008). DOI: 10.1016/j.jpowsour.2008.03.021

[3] R. M. Novais, M. P. Seabra, J. A. Labrincha, Porous geopolymer spheres as novel $\mathrm{pH}$ buffering materials. $J$. Clean. Prod. 143, 1114-1122 (2017).

DOI: https://doi.org/10.1016/j.jclepro.2016.12.008

[4] W. Lerdprom, C. Li, D. D. Jayaseelan, S. J. Skinner, W. E. Lee, Temperature dependence of electrical conductivity of a green porcelain mixture, J. Eur. Ceram. Soc. 37, 343-349 (2017).

DOI: https://doi.org/10.1016/j.jeurceramsoc.2016.08.019

[5] T. Yoshino, Laboratory electrical conductivity measurement of mantle minerals, Surv. Geophys. 31 (2), 163 206 (2010). DOI: 10.1007/s10712-009-9084-0

[6] K. Noritomi, Studies on the change of electrical conductivity with temperature of a few silicate minerals, Sci. Rep. Tohoku Univ. Ser. 5 Geophys., 6 (2), 119 (1954 ).

[7] G. Alberti, M. Casciola, in Proton Conductors Colomban, Ph., (Ed.), Cambridge: Cambridge University Press, 1992, pp. 238.
[8] Y.-I. Park, M. Nagai, J.-D. Kim, K. Kobayashi, Inorganic proton-conducting gel glass/porous alumina nanocomposite, J. Power Sources. 137, 175-182 (2004). DOI: 10.1016/j.jpowsour.2004.03.047

[9] H. Bae, J. Choi, G. M. Choi, Electrical conductivity of Gd-doped ceria film fabricated by aerosol deposition method, Solid State Ionics., 236, 16-21 (2013). DOI: https://doi.org/10.1016/j.ssi.2013.01.022

[10] M. Kahlaoui, S. Chefi, A. Inoubli, A. Madani, C. Chefi, Synthesis and electrical properties of co-doping with $\mathrm{La}^{3+}, \mathrm{Nd}^{3+}, \mathrm{Y}^{3+}$, and $\mathrm{Eu}^{3+}$ citric acid-nitrate prepared samarium-doped ceria ceramics, Ceram. Int. 39, 38733879 (2013).

DOI: https://doi.org/10.1016/j.ceramint.2012.10.230

[11] J. Jiang, W. Shen, J. L. Hertz, Structure and ionic conductivity of nanoscale gadolinia-doped ceria thin films, Solid State Ionics, 249-250, 139-143 (2013). DOI: https://doi.org/10.1016/j.ssi.2013.08.003

[12] E. Y. Pikalova, A. A. Murashkina, V. I. Maragou, A. K. Demin, V. N. Strekalovsky, P. E. Tsiakaras, $\mathrm{CeO}_{2}$ based materials doped with lanthanides for applications in intermediate temperature electrochemical devices, Int. $J$. Hydrogen Energ. 36, 6175-6183 (2011). DOI:10.1016/j.ijhydene.2011.01.132

[13] J. Prado-Gonjal, R. Schmidt, J. Espindola-Canuto, P. Ramos-Alvarez, E. Moran, Increased ionic conductivity in microwave hydrothermally synthesized rare-earth doped ceria $\mathrm{Ce}_{1-\mathrm{x}} \mathrm{RE}_{\mathrm{x}} \mathrm{O}_{2-(\mathrm{x} / 2)}$, J. Power Sources, 209 , 163-171 (2009). DOI: 10.1016/j.jpowsour.2012.02.082

[14] M. Stojmenović, S. Bosković, D. Bučevac, M. Prekajski, B. Babić, B. Matović, S. Mentus, Electrical characterization of multidoped ceria ceramics, Ceram. Int. 39, 12491255 (2013). DOI: https://doi.org/10.1016/j.ceramint.2012.07.055

[15] M. Stojmenović, S. Bošković, M. Žunić, J. A. Varela, M. Prekajski, B. Matović, S. Mentus, Electrical properties of multidoped ceria, Ceram. Int., 40, 9285-9292 (2014). DOI: https://doi.org/10.1016/j.ceramint.2014.01.151

[16] M. Stojmenović, S. Bošković, M. Žunić, B. Babić, B. Matović, D. Bajuk-Bogdanović, S. Mentus, Studies on structural, morphological and electrical properties of $\mathrm{Ce}_{1-\mathrm{x}} \mathrm{Er}_{\mathrm{x}} \mathrm{O}_{2-\delta}(\mathrm{x}=0.05-0.20)$ as solid electrolyte for ITSOFC, Mater. Chem. Phys., 153, 422-431 (2015). DOI https://doi.org/10.1016/j.matchemphys.2015.01.036

[17] M. Stojmenović, M. Žunić, J. Gulicovski, D. BajukBogdanović, I. Holclajtner-Antunović, V. Dodevski, S. Mentus, Structural, morphological, and electrical properties of doped ceria as a solid electrolyte for intermediatetemperature solid oxide fuel cells, J. Mater. Sci. 50, 3781-3794 (2015). DOI https://doi.org/10.1016/j.ceramint.2016.06.007

[18] N. Tian, J. Yu, Y. Deng, G. Li, X. Zhang, Electrical properties of $\mathrm{Ce}_{0.85} \mathrm{Sm}_{0.15} \mathrm{O}_{1.925}-\mathrm{Fe}_{2} \mathrm{O}_{3}$ electrolytes for IT-SOFCs, J. Alloy. Compd. 655, 215-219 (2016). DOI https://doi.org/10.1016/j.jallcom.2015.09.162

[19] M. R. Kosinski, R. T. Baker, Preparation and propertyperformance relationships in samarium-doped ceria nanopowders for solid oxide fuel cell electrolytes, J. Power Sources 196, 2498-2512 (2011). DOI: https://doi.org/10.1016/j.jpowsour.2010.11.041 
[20] D. Pérez-Coll, P. Núñez, J. R. Frade, The role of $\mathrm{SiO}_{2}$ and sintering temperature on the grain boundary properties of

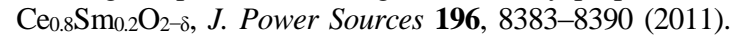
DOI: https://doi.org/10.1016/j.jpowsour.2011.06.075

[21] J. Wright, A. V. Virkar, Conductivity of porous $\mathrm{Sm}_{2} \mathrm{O}_{3}-$ doped $\mathrm{CeO}_{2}$ as a function of temperature and oxygen partial pressure, J. Power Sources, 196, 6118-6124 (2011). DOI: https://doi.org/10.1016/j.jpowsour.2011.03.043

[22] R. Waster, R. Hagenbeck, Grain boundaries in dielectric and mixed-conducting ceramics, Acta Mater. 48, 797-825 (2000). DOI: https://doi.org/10.1063/1.4936782

[23] S. Nenadović, Lj. Kljajević, M. Nešić, M. Petković, K. Trivunac, V. Pavlović, Structure analysis of geopolymers synthesized from clay originated from Serbia, Environ Earth Sci, 76-79 (2017). DOI: $10.1007 / \mathrm{s} 12665-016-6360-4$

[24] Lj. Kljajević, S. Nenadović, M. Nenadović, N. Bundaleski, B. Todorović, V. Pavlović and Z. Rakočević, Structural and chemical properties of thermally treated geopolymer samples, Ceram Inter $\mathbf{4 3}$, 9, 6700-6708 (2017).

DOI https://doi.org/10.1016/j.ceramint.2017.02.066

[25] K. Trivunac, Lj. Kljajević, S. Nenadović, J. Gulicovski, M. Mirković, B. Babić, S. Stevanović, Microstructural characterization and adsorption properties of alkali activated materials based on metakaolin, Sci. Sinter., 48, 209-220 (2016). DOI: 10.2298/SOS1602209T

[26] P. Duxson, G. C. Lukey, F. Separovic, J. S. J. van Deventer, Effect of alkali cations on aluminum incorporation in geopolymeric gels, Ind. Eng. Chem. Res. 44 (4), 832-839 (2005). DOI: $10.1021 / \mathrm{ie} 0494216$

[27] P. Innocenzi, Infrared spectroscopy of silica sol-gel films: A spectra-microstructure overview, J. Non Cryst. Solids, 316, 309-319 (2003) PII: S 0022-3093(02) 01637-X

[28] C. Karlsson, E. Zanghellini, J. Swenson, B. Roling, D.T. Bowron, L. Börjesson, Structure of mixed alkali/alkaline-earth silicate glasses from neutron diffraction and vibrational spectroscopy, Phys. Rev. B 72, 064206 (2005). DOI: 10.1103/PhysRevB.72.064206

[29] V. F. F. Barbosa, K. J. D. MacKenzie, Thermal behaviour of inorganic geopolymers and composites derived from sodium polysialate, Mater. Res. Bull. 38, 319-331 (2003 ). PII: S 0025-5408(02)01022-X
[30] D. Zaharaki, K. Komnitsas, V. Perdikatsis, Use of analytical techniques for identification of inorganic polymer gel composition, J. Mater. Sci. 45, 2715-2724 (2010). DOI: https://doi.org/10.1007/s10853-010-4257-2

[31] M. Roode, R. T. Hemings, Development of a unified Theory for Predicting Behavior of Glassy Waste Products) CANMET (Canada) Contract report No. ISQ8300162, July 1985, cited in Mehta

[32] S. Andrejkovičová, I. Janotka, P Komadel, Evaluation of geotechnical properties of bentonite from Lieskovec deposit, Slovakia, Appl. Clay Sci. 38, 297-303 (2008). DOI:10.1016/j.clay.2007.04.004

[33] W. K. W. Lee, J. S. J. van Deventer, Structural reorganisation of class F fly ash in alkaline silicate solutions, Colloids Surf.: Physicochemical and Engineering Aspects, 211(1), 49-66 (2002) PII: S 0927-7757(02) 00237-6

[34] M. Pires, X. Querol, Characterization of Candiota (South Brazil) coal and combustion by-product, Int. J. Coal Geol. 60, 57-72 (2004). DOI: 10.1016/j.coal.2004.04.003

[35] J. L. Provis, J. S. J. van Deventer, Direct measurement of the kintects of geopolymerisation by in-situ energy dispersive X-ray diffractometry. J. Mater. Sci. 42 (9), 2974-2981 (2007). DOI: 10.1007/s10853-006-0548-z

[36] Z. Sarbak, A. Stanczyk, M. Kramer-Wachowiak, Characterization of surface properties of various fly ashes, Pow. Techn. 145, 82-87 (2004). DOI:10.1016/j.powtec.2004.04.041

[37] R. R. Lloyd, J. L. Provis, J. S. J. van Deventer, Microscopy and microanalysis of inorganic polymer cements 1 : The gel binder J. Mater.Sci. 44 (2), 620-631 (2009). DOI: https://doi.org/10.1007/s10853-008-3078-z

[38] P. de Silva, K. Sagoe-Crentsil, V. Sirivivatnanon, Kinetics of geopolymerization : role of $\mathrm{Al}_{2} \mathrm{O}_{3}$ and $\mathrm{SiO}_{2}$. Cem. Concr. Res. 37, 512-518 (2007). DOI:10.1016/j.cemconres.2007.01.003

[39] S. H. Jensen, A. Hauch, P. V. Hendriksen, M. Mogensen, N. Bonanos, T. Jacobsen, A method to separate process contributions in impedance spectra by variation of test conditions, J. Electrochem. Soc. 154, B1325B1330 (2007). DOI: 10.1149/1.2790791 